\title{
HUBUNGAN ANTARA IMT DENGAN USIA MENARCHE PADA SISWI SD DAN SMP DI KOTA MANADO
}

\author{
${ }^{1}$ Sarah Stevany Munda \\ ${ }^{2}$ Freddy W Wagey \\ ${ }^{3}$ John Wantania
}

\begin{abstract}
Bagian Obstetri dan Ginekologi Fakultas Kedokteran Universitas Sam Ratulangi
Email: candys_kingdom@yahoo.co.id
\end{abstract}

\begin{abstract}
Menarche is the first menstruation experienced by woman. The improving standards of life will impact on the age of menarche (early menarche). There are many factors that affect the age of menarche, one of them is nutritional status. This research was aimed to analyze correlation between the nutritional status and age of menarche in female student of elementary school and junior high school at Manado city. This research used a cross sectional study. The subject was 196 female student. The data was analyzed using chi-square test. Research result showed that average age of menarche in elementary school is 10.63 \pm 0.72 and in junior high school is $11.34 \pm 1.35$. Based on test results $X^{2}$ (Pearson Chi Square) value obtained $X^{2}=68.742, p=0.000$. These results indicate that there is a highly significant association between IMT and age of menarche $(\mathrm{p}<0.01)$.
\end{abstract}

Keywords: Female student, Menarche age, Nutrinional status

\begin{abstract}
Abstrak: Menarche adalah menstruasi pertama yang dialami oleh seorang wanita. Membaiknya standar kehidupan berdampak pada penurunan usia menarche (menarche dini). Ada banyak faktor yang mempengaruhi usia menarche, salah satunya adalah status gizi. Penelitian ini bertujuan untuk menganalisis hubungan antara status gizi dan usia menarche pada siswi di SD dan SMP di Kota Manado. Penelitian ini menggunakan desain penelitian cross-sectional dengan sampel sebanyak 196 siswi. Data akan dianalisis dengan uji chi square. Hasil penelitian menunjukkan rata-rata usia menarche di SD adalah 10,63 \pm 0,72 dan SMP adalah 11,34 $\pm 1,35$. Berdasarkan hasil uji $X^{2}$ (pearson Chi Square) diperoleh nilai $X^{2}=68,742$ dengan $p=0,000$. Hasil ini menyatakan terdapat hubungan yang sangat bermakna antara IMT dan usia menarche $(\mathrm{p}<0,01)$.
\end{abstract}

Kata kunci: Siswi, Status gizi, Usia menarche

Masa remaja merupakan tahapan antara masa kanak-kanak dengan masa dewasa yang terjadi antara usia 10 hingga 18 tahun. Sebelum memasuki masa remaja seorang anak akan mengalami suatu periode yang dinamakan pubertas terlebih dahulu. Masa pubertas dalam kehidupan kita biasanya dimulai saat berumur 8 hingga 10 tahun dan berakhir lebih kurang di usia 15 hingga 16 tahun. $^{1}$ 
Masa pubertas pada wanita ditandai dengan pertumbuhan fisik yang cepat, menarche, perubahan psikologis dan timbulnya ciri-ciri kelamin sekunder.

Menarche merupakan menstruasi yang pertama kali dialami oleh wanita. Menarche dianggap sebagai hal yang penting karena menarche dikatakan sebagai puncak dari serangkaian perubahan seorang gadis yang sedang menginjak dewasa, dimana secara fisik pemunculannya ditandai dengan keluarnya darah dari vagina akibat peluruhan lapisan endometrium. $^{2,3}$ Menarche terjadi pada pertengahan pubertas atau biasa terjadi 6 bulan setelah mencapai puncak percepatan pertumbuhan. ${ }^{4}$

Membaiknya standar kehidupan berdampak pada penurunan usia menarche ke usia yang lebih muda. Hal ini telah dibuktikan oleh beberapa penelitian terdahulu. Diantaranya penelitian yang dilakukan oleh Viyantimala (2001) di Pekalongan terhadap usia menarche remaja putri yaitu berkisar pada angka 11,93 tahun. Penelitian yang dilakukan McAnarney (2003) menyatakan umur menarche remaja putri di Amerika mengalami penurunan dari 12,75 tahun menjadi 12,54 tahun. Penelitian yang sama juga dilakukan di India oleh Tiwari and Tiwari (2005) dimana terjadi penurunan usia menarche pada remaja putri dari 14,31 tahun menjadi 13,9 tahun.

Di Indonesia usia remaja pada waktu menarche bervariasi antara 10 hingga16 tahun dan rata-rata menarche pada usia 12,5 tahun. Usia menarche lebih dini terjadi pada gadis yang tinggal di daerah perkotaan dari pada yang tinggal di desa dan juga lebih lambat pada wanita yang kerja berat. ${ }^{6}$

Adapun faktor-faktor yang mempengaruhi usia menarche di antaranya adalah status gizi, genetik, keadaan lingkungan, status sosial ekonomi dan pendidikan. ${ }^{7}$

Dari beberapa faktor yang mempengaruhi usia menarche seseorang, status gizi menjadi salah satu faktor penting yang harus diperhatikan. Didapati bahwa remaja putri yang bergizi baik mempunyai kecepatan pertumbuhan yang lebih tinggi pada masa sebelum pubertas (prapubertas) dibandingkan dengan remaja yang kurang gizi. $^{8}$ Untuk mengetahui status gizi pada remaja dapat menggunakan rumus indeks massa tubuh atau yang biasa disingkat dengan IMT atau BMI (Body Mass Index), dimana cara perhitungannya dengan berat dalam kilogram dibagi dengan kuadrat dari tinggi badan dalam meter $\left(\mathrm{kg} / \mathrm{m}^{2)}{ }^{9}\right.$

Berdasarkan hal tersebut maka peneliti tertarik untuk meneliti hubungan antara status gizi yang dilihat berdasarkan perhitungan IMT (Indeks Massa Tubuh) dengan usia pertama kali menstruasi (menarche) pada siswi SD dan SMP di Kota Manado.

\section{METODE PENELITIAN}

Penelitian ini menggunakan metode penelitian Cross Sectional yaitu suatu penelitian yang mencoba mengetahui mengapa masalah kesehatan tersebut bisa terjadi kemudian dilakukan analisis hubungan antara faktor risiko dengan faktor efek. Penelitian ini dilaksanakan pada bulan November dan Desember 2012. Tempat penelitian di SD Katolik Santa Theresia 01, SD Katolik Santa Theresia 02, SD Katolik Santa Theresia 10, SD Katolik Santa Theresia Malalayang, SMP Katolik Santa Theresia Malalayang dan SMP Frater Don Bosco. Pada penelitian ini peneliti menggunakan rumus sampel jenuh atau total sampling dimana semua populasi dijadikan sebagai sampel penelitian. Besar sampel dalam penelitian ini sebanyak 196 siswi.

\section{HASIL PENELITIAN}

\section{A. Hasil Analisis Univariat \\ A.1 Status Menarche}

Dari hasil penelitian diperoleh 30 siswi $(15.3 \%)$ responden SD yang sudah mengalami menarche dan 204 siswi $(79.1 \%)$ yang belum mengalami menarche. Sedangkan pada responden SMP sebanyak 166 siswi $(84.7 \%)$ responden yang sudah mengalami menarche dan 54 siswi (20.9\%) responden yang belum mengalami menarche. 


\section{A.2 Usia Menarche}

Siswi SD mengalami menarche sebagian besar di usia 11 tahun berjumlah 14 siswi $(46.7 \%)$ responden. Usia menarche termuda responden SD adalah usia 9 tahun berjumlah 1 siswi ( $3.3 \%$ ) responden, dan tertua usia 12 tahun berjumlah 3 siswi (10\%) responden.

Siswi SMP mengalami menarche sebagian besar di usia 11 tahun berjumlah 62 siswi $(37.3 \%)$ responden. Usia menarche termuda responden SMP adalah usia 8 tahun berjumlah 3 orang $(1.8 \%)$ responden, sedangkan usia tertua adalah 15 tahun berjumlah 1 siswi $(0.6 \%)$ responden.

\section{B. Hasil Analisis Bivariat}

\section{B.1 Hubungan IMT dan Usia} Menarche Siswi

Uji yang digunakan adalah uji chi square dengan menggunakan data Indeks Massa Tubuh (IMT) dari responden kemudian dihubungkan dengan usia menarche dari responden. Hasil penelitian ini menunjukkan proporsi responden yang usia menarche tidak sesuai lebih banyak terdapat pada status gizi overweight sebanyak 32 siswi (51.6\%) responden, sedangkan usia menarche tidak sesuai dengan status gizi normal sebanyak 11 siswi (17.7\%)responden, dan usia menarche tidak sesuai dengan status gizi underweight sebanyak 19 siswi (30.6\%) responden.

Pada status usia menarche sesuai lebih banyak terdapat pada status gizi normal sebanyak 90 siswi (67.2\%) responden, sedangkan usia menarche sesuai dengan status gizi overweight sebanyak 6 siswi (4.5\%) responden, dan usia menarche sesuai dengan status gizi underweight sebanyak 38 siswi (28.4\%). Berdasarkan hasil uji $\mathrm{X}^{2}$ (Perason Chi Square) diperoleh nilai $X^{2}=68,742$ dengan $p=0,000$. Hasil ini menyatakan terdapat hubungan yang sangat bermakna antara IMT dan usia menarche $(\mathrm{p}<0,01)$.

Tabel 1. Distribusi Frekuensi Responden Berdasarkan Status Menarche Siswi

Sudah

Belum

Status Menarche Siswi

$\mathrm{SD}$

SMP

Jumlah n

30

166

196
$\%$

15.3

84.7

100 n $\%$

$204 \quad 79.1$

$\begin{array}{ll}54 & 20.9\end{array}$

$258 \quad 100$ 
Tabel 2. Distribusi Frekuensi Responden Berdasarkan Usia Menarche Siswi

\begin{tabular}{ccccc}
\hline Usia Menarche & \multicolumn{2}{c}{ SD } & \multicolumn{2}{c}{ SMP } \\
(Tahun) & n & \% & n & \% \\
\hline 8 & 0 & 0 & 3 & 1.8 \\
9 & 1 & 3.3 & 14 & 8.4 \\
10 & 12 & 40 & 17 & 10.2 \\
11 & 14 & 46.7 & 62 & 37.3 \\
12 & 3 & 10 & 45 & 27.1 \\
13 & 0 & 0 & 11 & 6.6 \\
14 & 0 & 0 & 13 & 7.8 \\
15 & 0 & 0 & 166 & 0.6 \\
\hline Jumlah & $\mathbf{3 0}$ & $\mathbf{1 0 0}$ & $\mathbf{1 0 0}$ & \\
\hline
\end{tabular}

Tabel 3. Distribusi Hubungan Antara IMT dengan Usia Menarche Siswi

IMT

Sesuai

n $\quad \%$

$38 \quad 28.4$

90

67.2

6

4.5

134

100

Overweight

Jumlah

$\%$

Underweight

Normal
Usia Menarche

Tidak Sesuai

\section{Jumlah}

n

$\%$

n

$\%$

19

30.6

57

29.1

11

$17.7 \quad 101$

51.5

32

51.6

38

19.4

62

100

196

100 


\section{PEMBAHASAN}

Terdapat banyak faktor yang mempengaruhi status menarche seseorang diantaranya faktor hormonal, faktor genetik, faktor bentuk badan, faktor keadaan gizi, faktor lingkungan, faktor aktivitas fisik, dan faktor rangsangan psikis. ${ }^{10}$ Akan tetapi dari beberapa faktor tersebut peneliti hanya meneliti variabel status gizi yang dilihat melalui perhitungan Indeks Massa tubuh (IMT).

\section{A. Status Menarche}

Kelompok responden terbagi atas 2 kelompok yaitu responden SD dan SMP. Responden SD yang sudah mengalami menarche sebanyak 30 siswi (15.3\%), sedangkan untuk responden SMP yang sudah mengalami menarche sebanyak 166 siswi (84.7\%).

Menarche adalah haid pertama yang terjadi, yang merupakan ciri khas kedewasaan seorang wanita dan tidak hamil. Terjadinya menstruasi dipengaruhi oleh hormon estrogen dan progesteron yang diproduksi di dalam indung telur. Indung telur menghasilkan estrogen setelah keluarnya darah menstruasi dan progestreron setelah terjadi ovulasi atau pelepasan sel telur dari indung telur. Hormon estrogen menyebabkan penebalan selaput lendir pada dinding rongga rahim dan selaput lendir ini akan menjadi sembab dibawah pengaruh progesteron. Bila tidak terjadi kehamilan, kadar kedua hormon ini akan menurun dan menyebabkan selaput lendir terlepas dari dinding rongga rahim yang disertai dengan perdarahan menjadi darah menstruasi. ${ }^{11}$

\section{B. Usia Menarche}

Berdasarkan hasil riset kesehatan dasar tahun 2010, 5.2 \% anak di 17 provinsi di Indonesia telah memasuki usia menarche dibawah usia 12 tahun. Indonesia sendiri menempati urutan ke15 dari 67 negara dengan penurunan usia menarche mencapai 0.145 tahun per dekade. ${ }^{3}$

Penilaian usia menarche pada penelitian ini menggunakan metode wawancara, dimana peneliti bertanya langsung kepada responden mengenai kapan pertama kali responden mengalami menstruasi (menarche). Berdasarkan wawancara tersebut di dapatkan hasil, untuk responden SD usia menarche dimulai pada usia 9 hingga 12 tahun dengan rata-rata usia menarche $10.63 \pm 0.72$. Hasil tersebut hampir sama dengan peneletian sebelumnya yang dilakukan oleh Ema Nur Fitriana (2012) terhadap siswi Sekolah Dasar Negri 1 Kleco Surakarta, didapatkan rata-rata usia menarche siswi Sekolah Dasar Negri 1 Kleco Surakarta $10.72 \pm$ $0.89 .^{12}$

Sedangkan untuk responden SMP usia menarche dimulai pada usia 8 hingga 15 tahun dengan rata-rata usia menarche $11.34 \pm 1.35$. Hasil yang tidak jauh beda juga terdapat pada penelitian sebelumnya yang dilakukan oleh Pebri Warita Pulungan (2009) terhadap siswi SMP Shafiyyatul Amaliyyah Kota Medan dengan usia rata-rata menarche siswi adalah $11.45 \pm 0.92{ }^{13}$

Hasil ini menunjukkan bahwa saat ini telah terjadi pergeseran usia menarche ke usia yang lebih muda dibandingkan dengan generasi sebelumnya. Hal ini juga diperkuat oleh penelitian yang dilakukan di Amerika Serikat yang menunjukkan usia menarche rata-rata telah berkurang dari 12.75 kepada 12.54 tahun. Pada penelitian yang sama di Netherlands, menunjukkan usia pubertas rata-rata telah berkurang dari 11 tahun ke 10.7 tahun. ${ }^{14}$

\section{Hubungan Indeks Massa Tubuh (IMT) dengan Usia Menarche}

Status gizi remaja wanita sangat berpengaruh terhadap terjadinya menarche baik dari faktor usia menarche, keluhan-keluhan selama menarche maupun lamanya menarche. Untuk menentukan status gizi remaja dapat menggunakankan Antropometri. Antroprometri merupakan cara penentuan status gizi yang paling mudah dan murah. Indeks Massa Tubuh (IMT) direkomendasikan sebagai indikator yang baik untuk menentukan status gizi remaja $^{15}$ 
Berdasarkan hasil perhitungan Indeks Massa Tubuh (IMT) yang dilakukan terhadap responden SD dan SMP yang kemudian dihubungan dengan usia menarche responden maka hasil yang didapatkan adalah usia menarche tidak sesuai terbanyak terdapat pada siswi dengan status gizi overweight dengan presentase $51.6 \%$. Sedangkan untuk usia menarche sesuai terbanyak terdapat pada siswi dengan status gizi normal dengan presentase $67.2 \%$.

Hasil uji statisktik hubungan antara IMT (Indeks Massa Tubuh) dengan usia menarche didapatkan $\mathrm{p}$ value 0.000 ( $\mathrm{p}<0.01)$. Hal ini berarti terdapat hubungan yang sangat bermakna antara IMT dengan usia menarche. Hal ini sejalan dengan beberapa penelitian salah satunya penelitian yang dilakukan oleh Lalu Wirasenta (2011), yang dilakukan pada siswi SD di Provinsi Nusa Tenggara Barat, dimana didapati hasil yang hampir sama yaitu $p=0.000(p>0.05)$ sehingga dapat ditarik kesimpulan bahwa terdapat hubungan antara status gizi dan usia menarche. ${ }^{16}$

\section{KETERBATASAN}

Dalam penelitian ini, peneliti masih menemukan berbagai keterbatasan penelitian, diantaranya jumlah sampel dan waktu yang terbatas serta data menstruasi pertama kali kurang objektif karena dilakukan hanya dengan wawancara dan beberapa responden lupa akan usia pertama kali menstruasi.

\section{SIMPULAN}

Berdasarkan hasil dan pembahasan yang diperoleh, dapat ditarik kesimpulan bahwa terdapat hubungan yang bermakna antara IMT (Indeks Massa Tubuh) dengan usia menarche. Dimana didapatkan bahwa siswi dengan status gizi overweight lebih cepat mengalami menstruasi dibandingkan siswi yang berstatus gizi normal dan underweight.

\section{SARAN}

1. Bagi pihak sekolah

Dengan kecenderungan semakin muda usia rata-rata menarche, maka perlu diadakan penyuluhan mengenai kesehatan reproduksi dan faktor-faktor yang mempengaruhi menarche pada remaja putri terutama faktor yang berhubungan dengan status gizi. Sehingga orang tua dapat mengatur asupan gizi anaknya agar seimbang.

2. Bagi peneliti selanjutnya Perlu penelitian lebih lanjut mengenai faktor-faktor yang berhubungan dengan status menarche lainnya, dan dengan menggunakan desain penelitian analitik lainnya serta menggunakan jumlah sampel yang lebih besar sehingga dapat memberikan hasil yang lebih baik.

\section{UCAPAN TERIMA KASIH}

Disampaikan kepada dr. Rudy A. Lengkong (K) dan dr. Junneke Kaeng, SpOG(K) serta semua yang baik secara langsung maupun tidak langsung telah menumbuhkan ide tau gagasan dalam pemikiran penulis 


\section{DAFTAR PUSTAKA}

1. Swasta E. Fisiologi Reproduksi wanita. Diunduh dari URL: staff.uny.ac.id/.../Oahraga\%20dan\%20 Fisiologi diakses pada tanggal 9 Oktober 2012.

2. Taber Ben-zion. Perdarahan Per Vaginam. S Melfiawati, Editor. Kapita Selekta Kedaruratan Obstetri dan Ginekologi. Alih bahasa: Supriyadi T. Jakarta: EGC; 1994. P 459.

3. Santrock JW. Adolescence Perkembangan Remaja. Wisnu C, Kristiaji, Sumiharti Y. Alih bahasa: Seragih S, Shinto B. Jakarta: Erlangga; 2003. P 84-92.

4. Karapanao O, Anatasios P. Determinants of Menarche. Diunduh dari URL: www.biomedcentral.com diakses pada tanggal 23 Oktober 2012.

5. Putri AK. Hubungan Antara Status Gizi, Status Menarche Ibu, Media Massa, Aktifitas Olahraga dengan Status Menarche Siswi di SMP Islam Al-azhar rawamangun Jakarta Timur. Diunduh dari URL: www.lontar.ui.ac.id/file=digital/124272 -S-5676...pdf diakses pada tanggal 24 Oktober 2012.

6. Winkjosastro

$\mathrm{H}$, Saifuddin $\mathrm{AB}$, Rachimhadhi trijatmo. Ilmu Kandungan. Edisi 2. Jakarta: PT Bina Pustaka Sarwano Prawirohardjo; 2009. P 92-104.

7. Gaudineau et al. Factors associated with early menarche: results from the French Health Behaviour in Schoolaged Children (HBSC) study. Diunduh dari URL: http://www.biomedcentral.com/14712458/10/175 diakses pada tanggal 24 oktober 2012 .

8. Yatim F. Penyakit Kandungan Myom, Kista, Indung Telur, Kanker Rahim/Leher Rahim, serta Gangguan Lainnya. Jakarta: Pustaka Populer Obor; 2005. P 13.
9. Anonimus. Global Database On Body Mass Index. Diunduh dari URL: apps. who.int/bmi/index.jsp?infopage $=$ in tro_3.html diakses pada tanggal 17 September 2012.

10. Daniels, Stephen R. et al, 1997. The Utility of Body Mass Index as a Measure of Body Fatness in Children and Adolescents: Differences by Race and Gender. PEDIATRICS Vol. 99 No. 6 June 1997, pp. 804-807 (doi:10.1542/peds.99.6.804).

11. Tjong C. Mengenal Menarche Si Menstruasi Pertama. Diunduh dari URL: rspondokindah.co.id/.../611Ginekologi-167-K diakses pada tanggal 8 Januari 2013.

12. Fitriana EN. 2012. Hubungan Status Gizi dengan Rata-rata Usia Menarche Pada Siswi Sekolah Dasar Negri 1 Kleco Surakarta. Diunduh dari URL: http://fk.uns.ac.id/index.php/abstraks kripsi/baca/466 diakses pada tanggal 8 Januari 2013.

13. Pulungan PW. 2009. Gambaran Usia Menarche Pada Remaja Putri di SMP Shafiyyatul Amaliyyah dan SMP Nurul Hasanah Kota Medan Tahun 2009. Diunduh dari URL: repository.usu.ac.id/bitstream/.../1/09 E02903.pdf diakses pada tanggal 8 Januari 2013.

14. Biro FM, Wien M Childhood Obesity and Adult Morbidities. Diunduh dari URLhttp://www.ncbi.nlm.nih.gov/pm c/articles/PMC2854915/diakses pada tanggal8 Januari 2013.

15. Permaisih. 2003. Status gizi remaja dan faktor-faktor yang mempengaruhinya. Diunduh dari URL:

http://digilib.litbang.depkes.go.id/go. php?id=jkpkbppk-gdl-res-2003permaisih-886-gizi [20 Desember 2010] diakases pada tanggal 9 Januari 2013. 
16. Wirasenta L. 2011. Hubungan Status Gizi Anak, Status Sosial ekonomi Orang Tua dan Paparan Media Dengan Usia Menars Pada Siswi Sekolah Dasar (SD) Provinsi Nusa Tenggara Barat. Diunduh dari URL: http://www.pps.unud.ac.id diakses pada tanggal 8 Januari 2013. 